\title{
LIGHT LAND PASTURES
}

$\therefore$ C. E. IVERSEN, Senior Lecturer in Agriculture, and J. W. CALDER, Professor of Agricultural Botany, Canterbury Agricultural College, Lincoln.

Approximately $\frac{8}{4}$ million acres of the Canterbury Plains are classified as light land. The soils are a shallow, stony loam overlying an open, shingle subsoil with a very low moisture holding capacity. The rainfall of 25in. is fairly well distributed, but on these soils is normally inadequate for pasture growth from November to March, due to high evaporation. Under these conditions the pasture mixtures used on moister soils are unsuitable. Subterranean clover has proved the most suitable pioneer legume for this class of land and is still the basic legume for most pasture mixtures.

Investigations into the management and productivity of subterranean clover were made at Ashley Dene from 1939 to 1947 . This work showed that subterranean clover was a first-class legume for these soils and that it was essential to apply both lime and superphosphate before a vigorous stand of clover could be secured. (1)

The second stage of the investigations was a study of the clover in relation to other species in the mixture. This paper presents the results of this investigation over the past 6 years.

Mixtures Used

"A" Series : A high-producing series from the previous investigation on fertiliser treatments-an old (1937) subterranean clover pasture with low density grass. Fertiliser was lcwt of superphosphate and 5cwt of lime in alternate yeanss. This was considered to be the standard pasture for comparison.

"B" Series: Similar to the "A" series, but low-producing, due to poor clover. Treatment has been $2 \mathrm{cwt}$ of superphosphate annually with no lime. This series was continued as a museum piece.

Phalaris : Sown March 1948 ; 51b of Phalaristuberosa and $21 \mathrm{~b}$ of subterranean clover.

Ryegrass: Sown March 1948; 20lb of perennial ryegrass and $2 \mathrm{lb}$ of subterranean clover. 
Cocksfoot: Sown March 1948; 10lb of cocksfoot and $21 \mathrm{~b}$ of subterranean clover.

Lucerne-Phalaris : Sown September $1949 ; 10 \mathrm{lb}$ of lucerne, 5lb of phalaris, and $2 \mathrm{lb}$ of subterranean clover.

Top-worked Ryegrass: The ryegrass fields had become weak in clover by 1953 and one field was topworked in February 1953 and 1954. Fertiliser treatments for all except "B" series were the same as for the "A" series.

On this class of land there is a very slow establishment phase and the results presented herein are given from autumn 1950 to summer 1956. Autumn (March, April, May) is taken as the commencement of a season, as the annual subterranean clover germinates at that time and the season is partly governed by the vigour of the germination. Weather data for the 6 years under review are given in Table 1.

Table I--Weather Data 1950-56, Lincoln College

\begin{tabular}{|c|c|c|}
\hline Year & Rainfall (in.) & Evaporation \\
\hline $1950-51$ & 35.15 & 25.17 \\
\hline 1951-52 & 31.00 & 27.84 \\
\hline $1952-53$ & 30.86 & 25.28 \\
\hline 1953-64 & 27.25 & 22.09 \\
\hline 1954-55 & 21.67 & 30.17 \\
\hline 1955-56 & 21.61 & 32.47 \\
\hline
\end{tabular}

Two-thirds of the pasture production of these soils is made in the spring months of September, October, and November and consequently annual rainfall and evaporation are not necessarily correlated with production. Spring moisture, on the other hand, gives an accurate picture of productivity. This is shown in Table 2, where spring rainfall and potential transpiration calculated according to Penman's ${ }^{(2)}$ formula are compared with the average production of all plots.

If the spring rainfall were evenly distributed throughout the 3 months, a net moisture of zero should give maximum production. This is obviously not the case. However, Penman's factor of .7 may be too low under the conditions and the estimated soil surplus may be too high.

Before examining the results of using different mixtures a consideration of the strengths and weaknesses of the standard pasture is desirable. The stand- 
ard subterranean clover pasture as typified by the " $\mathrm{A}$ " series is a high-producing sward and many of the mixtures tried have failed to reach the same production.

Table S-Spring Moisture and Production,

\begin{tabular}{|c|c|c|c|c|}
\hline Year & $\begin{array}{l}\text { Spring } \\
\text { Rain } \\
\text { (in.) }\end{array}$ & $\begin{array}{l}\text { Evapo- } \\
\text { transpira- } \\
\text { tion (in.) }\end{array}$ & $\begin{array}{l}\text { Net } \\
\text { Moisture } \\
\text { (in.) }\end{array}$ & $\begin{array}{c}\text { Annual } \\
\text { Pasture } \\
\text { Production } \\
\mathbf{1 9 5 0 - 5 6} \\
-100\end{array}$ \\
\hline 1950 & 6.59 & 7.60 & -0.01 & $\overline{114}$ \\
\hline 1951 & 5.49 & 7.51 & -1.02 & 75 \\
\hline 1952 & 11.48 & 6.68 & +5.80 & 162 \\
\hline 1953 & 5.57 & 5.67 & +0.90 & 120 \\
\hline 1954 & 3.63 & $9: 42$ & 4.79 & 53 \\
\hline 1955 & 4.39 & 7.98 & -2.59 & 62 \\
\hline
\end{tabular}

Winter soil moisture surplus $=$ lin.

The essential features of the sward are as follows :

1. A low density of perennial species and a high density of annual species. The average percentage of constituents over the 6 years is:

\begin{tabular}{ccc} 
Subterranean clover & \multicolumn{2}{c}{ Percent } \\
Perennial grasses, mainly rye- & 31 \\
grass & ' & 31 \\
Annual weeds 'and weed grasses & 38
\end{tabular}

The low density of perennials has an important bearing on germination of the clover in autumn.

2. Spring production is 66 per cent of the total and requires special flock management, such as early lambing and early drafting of light-weight lambs and provision of supplementary feed for winter and early spring.

3. Annual production is very variable (coefficient of variability 55 per cent). The main variation is in

clover growth. In an average season the clover germinates in the early autumn and is well estab-

lished by winter. A small winter growth is followed by an intense spring flush which dies off in November but provides paddock roughage for the summer. Flowering occurs from early October and results in a reasonable build-up of seed in the soil. In wet seasons $\frac{1}{2}$ ton per acre of seed' may be set but in dry seasons the clover may dry off before seed is set. This is important in a new pasture, but is normally of little consequence in an old pas- 


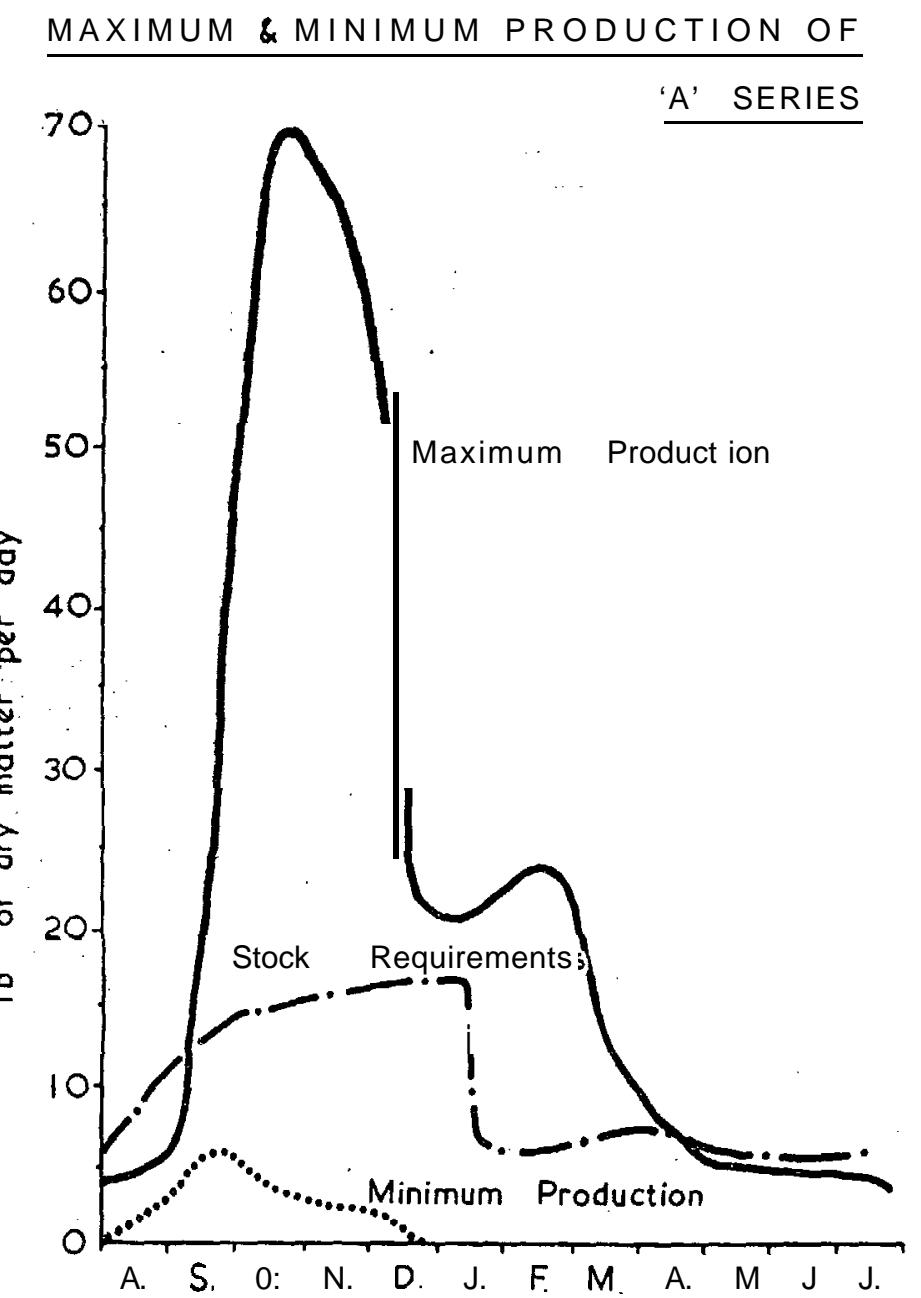

ture where regeneration can occur from hard seed. If autumn moisture is unfavourable, seed may fail to germinate; it may germinate early and fail to survive or germinate late and be killed by frost lift. A legume less subject to the vagaries of climate would be of value.

In Table 3 the seasonal production of the " $A$ " series is given for the period 1950-56.

When related to the weather data in Tables 1 and 2 , together with the factor of germination discussed above, the reasons for variability in production are 
Table 3-Seasonal Production "A" Series 1950-56.

Seasons

\begin{tabular}{|c|c|c|c|c|c|}
\hline Year & $\overline{\text { Autumn }}$ & $\begin{array}{l}\text { Winter } \\
\text { lb of }\end{array}$ & $\begin{array}{l}\text { Spring } \\
\text { dry matter }\end{array}$ & Summer & Total \\
\hline 1950-51 & 666 & 433 & $\overline{1950}$ & $\overline{1313}$ & 4362 \\
\hline $1951-52$ & 387 & 81 & 1460 & 232 & 2160 \\
\hline $1952-53$ & 10 & 20 & 4366 & 1622 & 6018 \\
\hline 1953-54 & $\$ 445$ & 297 & 2948 & 380 & 4070 \\
\hline 1954-55 & 103 & 39 & 422 & 357 & 921 \\
\hline $1955-56$ & 144 & 168 & 1938 & 16 & 2266 \\
\hline $1950-56$ & 293 & 373 & 2181 & 653 & 3300 \\
\hline $\begin{array}{l}\text { Percentage } \\
\text { production }\end{array}$ & $9 \%$ & $5 \%$ & $66 \%$ & $20 \%$ & \\
\hline
\end{tabular}

apparent. Although average production is high, the extreme variability and the poor seasonal spread justify the search for superior species. In one respect subterranean clover rates highly, that is, as a stock' feed. We have as yet found no nutritional troubles with these swards. A comparison of the different mixtures used is therefore made on the basis of average production, variability, seasonal production, and nutritional value.

\section{Average Production}

Table 4 gives the average production of the 7 mixtures for the years 1950-56.

\section{AVERAGE PRODUCTION OF A SERIES TO STOCK REQUREMENTS}

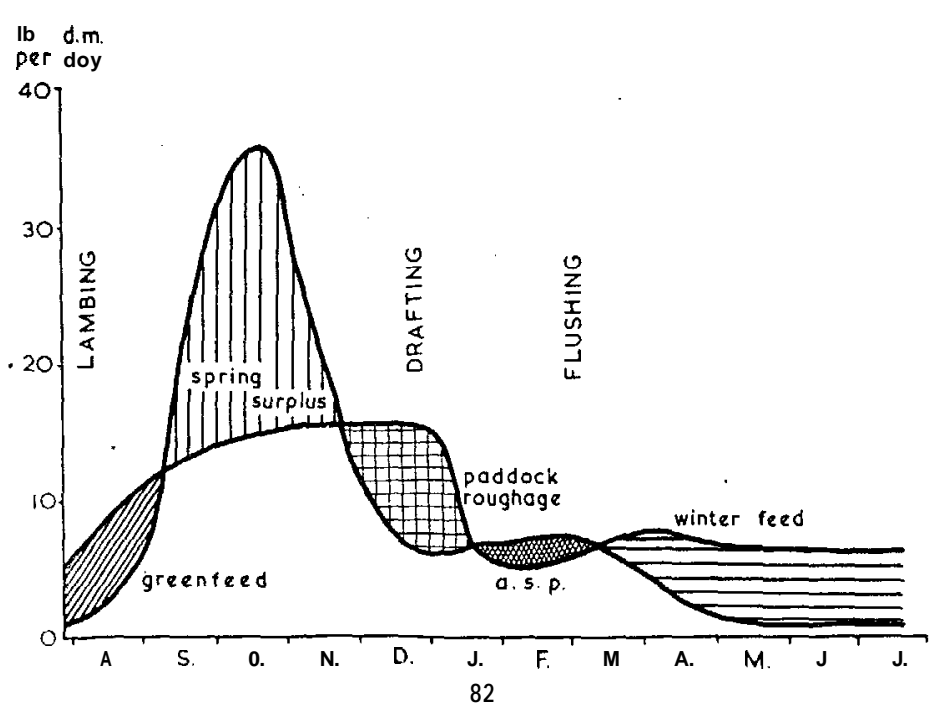


Table I-Average Production of Seven M ixtures, Field 18, Ashley Dene, 1950-56

Yield in lb dry matter per acre

\begin{tabular}{|c|c|c|c|c|c|}
\hline \multirow[b]{2}{*}{ Mixture } & \multirow{2}{*}{$\begin{array}{l}\text { Sown } \\
\text { Grass }\end{array}$} & \multicolumn{3}{|c|}{ Subterranean } & \multirow[b]{2}{*}{ Total } \\
\hline & & Weed & 'Clover & Lucerne & \\
\hline 1. Phalaris & $\overline{12} 6 \overline{7}$ & $\overline{925}$ & $\overline{625}$ & - & 2817 \\
\hline 2. "A" series & 1007 & 1268 & 1025 & $=$ & 3300 \\
\hline 3. "B" series . & 355 & 1115 & 180 & & 1650 \\
\hline 4. Lucerne-Phal- & & & & & \\
\hline $\begin{array}{c}\text { aris } \\
\text { 5. Ryegrass }\end{array}$ & $\begin{array}{l}1613 \\
1428\end{array}$ & $\begin{array}{l}728 \\
587\end{array}$ & $\begin{array}{l}607 \\
610\end{array}$ & $\begin{array}{r}1627 \\
-\end{array}$ & $\begin{array}{l}4575 \\
2625\end{array}$ \\
\hline 6. Cocksfoot (1) & 1328 & 497 & 511 & - & 2336 \\
\hline $\begin{array}{l}\text { 7. Top-worked } \\
\text { ryegrsss (2) }\end{array}$ & 850 & 1230 & 1310 & - & 3390 \\
\hline
\end{tabular}

(1) For seasons 1950-53 only. Adjusted to 6-year average.

(2) For seasons 1953-55 only. Adjusted to 6-year average.

Significant difference of totals at $5 \%=826$

Significant difference of totals at $1 \%=1142$

\section{Comments on Table 4}

Only one mixture is superior to the "A" series, i.e. lucerne-phalaris-subterranean clover mixture. This has been significantly better in each of the 6 years. The contribution of sown grasses, weeds, and subterranean clover at $2948 \mathrm{lb}$ is about average, but superimposed on this is a yield of $1627 \mathrm{lb}$ of lucerne. The differences in yield of the 7 mixtures are largely accounted for by differences in yield of the legumes.

The "A" series with a low density of perennial grass usually has a high percentage of clover, as does the top-worked ryegrass for the same reason. The mixtures with a high density perennial grass such as cocksfoot and ryegrass inhibit the germination of subterranean clover in all except the most favourable autumns and consequently are low in clover. The " $\mathrm{B}$ " series, being inadequately fertilised for clover, is seriously affected in clover growth and growth of sown grasses. "Weeds" consist of hair grass, sweet vernal, and such plants as storksbill. These are at a minimum in swards of high density perennial grasses.

\section{Annual Variability}

It was noted above that the "A" series had a coefficient of variability of 55 per cent. It was expected that the use of perennial grasses would reduce variability considerably, as such mixtures are less subject 
to vagaries of germination. However, a compensating factor occurs with the legume. With high density grasses subterranean clover is even more unreliable and the low'nitrogen status lowers grass production. The perennial legume lucerne is least subject to annual variation. The coefficient of variability of the principal mixtures is :

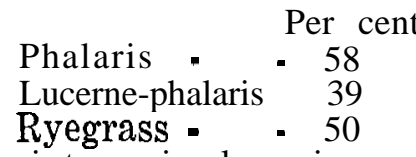

The cocksfoot mixture is low in variability, but achieves this by being uniformly poor.

\section{Seasonal Production}

Table 5 gives the seasonal production of the principal mixtures as percentages of the mixture totals, but for comparison the actual yield should be, taken into account.

Table 5-Percentage Seasonal Production of Six Mixtures,

\section{0-1956}

\begin{tabular}{|c|c|c|c|c|}
\hline Mixture & Autumn & Winter & Spring & Summer \\
\hline Phalaris & 14 & 9 & 55 & 22 \\
\hline "A" series & - & 5 & 66 & 20 \\
\hline Lucerne-phalaris & - 12 & 10 & 54 & 24 \\
\hline Ryegrass & - 12 & 3 & 62 & 23 \\
\hline Cocksfoot & .15 & 3 & 56 & 26 \\
\hline Top-worked rye & ass 5 & 13 & 69 & 13 \\
\hline
\end{tabular}

The use of different species has tended to spread production. Phalaris has some advantages for autumn and winter production, as is shown in both the phalaris and lucerne-phalaris mixtures. Lucerne gives good summer production; cocksfoot is valuable in summer and autumn, but is inferior in winter. The best general pattern is given by the lucerne-phalaris-subterranean clover mixture.

\section{Nutritional Value}

The two species about which there may be 'some reservations are phalaris and lucerne. Where phalaris forms a major portion of the diet stock health may be affected, but in the mixture used here there have been no noticeable adverse effects. V. R. Clark commenced a field trial of some of these mixtures in 1954. Ewes and lambs were used for grazing and records' kept of fat lamb production. The two seasons of the trial to date have been dry. A wet season may show up defici- 
encies in the nutritional value of the lucerne mixture, but so far the lucerne mixture has carried more ewes and lambs and the daily weight gain per lamb has been as good as on other mixtures. The dry matter production of the three fields is given in Table 6 , as it confirms on a field scale the evidence from plot work presented earlier.

Table 6-Production of Three Light Land Pastures 1954-55.

(in lb dry matter per acre)

\begin{tabular}{|c|c|c|c|c|c|}
\hline 1954-55 & Winter & Spring & Summer & Autumn & Total \\
\hline 1. Ryegrass pasture & $11 \mathrm{c}$ & & & & \\
\hline $\begin{array}{l}\text { first year - } \\
\text { 2. Ryegrass pasture }\end{array}$ & - 1164 & 1417 & 405 & 238 & 3224 \\
\hline $\begin{array}{l}\text { second year } \\
\text { 3. Lucerne, phalaris, } \\
\text { teranean clover }\end{array}$ & sub- 62 & 217 & 339 & 341 & 959 \\
\hline $\begin{array}{l}\text { eighth year - } \\
1955-56\end{array}$ & - 352 & 1703 & 1061 & 531 & 3647 \\
\hline 1. Ryegrass pasture & - $\quad 258$ & 556 & 39 & 326 & 1169 \\
\hline $\begin{array}{l}\text { 2. Ryegrass pasture } \\
\text { third y e a r - } \\
\text { 3. Lucerne, phalaris, } \\
\text { terranean clover }\end{array}$ & $\begin{array}{l}-\quad 63 \\
\text { sub- }\end{array}$ & 469 & 50 & 531 & 1113 \\
\hline ninth year & - 336 & 3067 & 421 & 190 & 4014 \\
\hline
\end{tabular}

The ryegrass pasture is a standard mixture for this class of land. It shows up well in the first winter and spring, but in the second and third year in dry seasons tends to become cloverless. When most of the ryegrass has died the clover will gradually thicken up and give a good pasture akin to the "A" series. The lucerne pasture used in this trial was sown in 1947 with $31 \mathrm{~b}$ of Medicago glutinosa, $5 \mathrm{lb}$ of phalaris, and $21 \mathrm{~b}$ of subterranean clover. $M$. glutinosa is a rhizomatous strain with a low crown and good sward-forming characteristics. In this field it provides 70 per cent of the total production and its performance has encouraged us to embark on a programme of selection and breeding with the species.

\section{Discussion}

Initial Pasture Improvement : The establishment of high-producing swards of subterranean clover 'and a Perennial grass on this class of land is possible but difficult. The standard mixture of a' high density 
grass such as one bushel of 'ryegrass gives a good firstyear growth, but then passes through a low-producing cloverless phase for several years. This can be prevented in one of four ways. In the more difficult environments a pure sowing of subterranean clover can be made in autumn. Greenfed oats may be added without harm. October grazing should be avoided. A good seed setting should result and in the absence of competition a good germination should be secured the following autumn. A light seeding of grasses can be surface introduced into the sward within a few years. On better land the grass component can be broadcast in front of the drill and the clover drilled with the manure. Such a sowing gives a scattered grass component akin to the "A" series. Where they are drilled together, a suggested mixture is $51 \mathrm{~b}$ of perennial ryegrass, llb of cocksfoot, and $31 \mathrm{~b}$ of phalaris with $4 \mathrm{lb}$ of subterranean clover ; $21 \mathrm{~b}$ of short-rotation ryegrass may be added to provide competition for weeds in the initial stages and for winter production, and $\frac{1}{2} \mathrm{lb}$ of white clover to take advantage of any subsequent build-up in fertility. Where ryegrass is to be cut for seed in the first year a heavier seeding may be used. In the absence of grazing there is a good seeding of clover and the ryegrass is weakened by seed production.

Pasture Renovation. Old pastures of subterranean clover which may have become grass or weed dominant due to the build-up of nitrogen can be renovated by top-working in January. The field is quickly worked with grubber or discs and harrows and rolled down to conserve moisture. If considered desirable a light seeding of grass may be drilled in. Where winter and early spring feed are desired, $10 \mathrm{lb}$ of short-rotation ryegrass can be sown with advantage.

Lucerne Pastures. Lucerne has been used increasingly on these soils, but mainly as a source of hay with a little grazing. While this still has an important place, we believe there should be a development of lucerne pasture mixtures devoted almost entirely to grazing. The lucerne mixture used in these investigations has given 40 per cent more production than the next best mixture and 100 per cent more than some of the high density perennial grass mixtures. It has a lower variability due to vagaries of climate and has a better seasonal spread. In a well-balanced mixture nutritional troubles have not been apparent. A combination of subterranean clover, cocksfoot, and phalaris with the lucerne appears to be suitable. 
The strain of lucerne to be used is the matter of some controversy. An early sativa strain is very productive 'and its early spring growth is valuable at lambing. With careful grazing it will last in the sward for many years. M. glutinosa is later in spring, but has sward-forming characteristics which permit severe and continued grazing in times of scarcity of feed. It has shown greater longevity under these conditions than M. sativa. A compromise may be to include both strains in the mixture. Success can be achieved with several seed mixtures, e.g.,

(a) 8lb Marlborough lucerne , $21 \mathrm{~b}$ cocksfoot

$41 \mathrm{~b}$ subterranean clover.

(b) 5lb Marlborough lucerne

3lb M. glutinosa

$21 \mathrm{~b}$ cocksfoot

3lb phalaris

$4 \mathrm{lb}$ subterranean clover.

(c) $41 \mathrm{~b}$ M. glutinosa

2lb cocksfoot

$21 b$ perennial ryegrass

2lb short-rotation ryegrass

$\frac{1}{2} l b$ white clover

$41 \mathrm{~b}$ subterranean clover.

Variations may be made within these.

Such mixtures are best sown in the spring after a winter fallow; late September is most suitable in this district. The subterranean clover is an important component of the mixture and with spring sowing it may fail to set seed. In this event it should be oversown the following autumn. However, our view is that the pioneer stage of development of the lighter lands is the establishment of good subterranean clover pastures akin to the " $A$ " series. Once fertility has been built up in this way the stage is set for a higher phase of production with the lucerne pasture.

\section{Acknowledgments}

This investigation was made possible by a financial grant from the Department of. Scientific and Industrial Research to whom grateful acknowledgment is . made. We are also indebted to the College Board of Governors who provided land, stock, and labour, and to the Farm Manager at Ashley Dene for supervision.

\section{References}

(1) J. W. Calder: Lincoln College Technical Bulletin No. 6.

(2) H. L. Penman: Agric. Progress, Vol. 27, 195‘2. 


\section{DISCUSSION}

Q. Have you any idea of the prospects of establishing subterranean clover on the light land of northern Southland? Would it be possible to do so ?

A. Northern Southland is not an area I know well. A Tarras farmer was using subterranean clover there excellently and the conditions are harder than with you. It frequently does germinate too late and gets frosted. 'If your moisture comes in time to get it germinated and established before the frost it should be all right.

T. G. Sewell. Two varieties have been established in the Riversdale area. Tallarook and Mt Barker. One nasture has been established 12 years but I do not know how much super has been put on. This year molybdenised super was used with good results.

Q. If part of each area of subterranean clover were cultivated each autumn, would that not help to ensure a strike of seedlings?

A. Yes.

Q. What about bloat in the grazing of lucerne pastures? Does it occur in New Zealand? It is the worst problem we are up against in the United Kingdom.

A. Perhaps you can cast your mind back to rainfall conditions, humidity and evaporation in the summer period. You remember the figure for weeds in these pastures. The sheep do not eat pure lucerne so there is no bloat problem so far as sheep are concerned. There are different weather conditions and a different composition of pasture here.

Q. You mention sowing $61 \mathrm{~b}$ of subterranean clover, whereas U.K. farmers sow only $61 \mathrm{~b}$ of total seed for the same area. What quantity of seed do you sow to the acre? Three pounds of ryegrass could be sufficient to the acre. If the ground is very fertile do you want a-lot of seed or a small quantity of seed? A bushel of ryegrass will give 100 plants to the square foot.

A. It would be generally accepted and probably partly proved that the more fertile land will support more plants and have a higher rate of seed. To what extent it is proven I do not know. Once I was against light seeding; after my overseas visit I was convinced of the importance of low seeding rates, and that .we should reduce ours.

Sir Brace Levy. On light land as you build fertility the ryegrass will come back on subterranean clover pastures whether you once had it or not. The more you can get ryegrass with subterranean clover the more advanced your pasture will be towards a final product. You can take perennial ryegrass as being the yardstick with which you can measure. The drier the soils the fewer the seed you sow. High seed rate is better than low seed rate for establishment of permanent pasture. High grade land will have better production with higher seeding rate. It was not until we got past $45 \mathrm{lb}$ per acre that we got inter-species competition. At 55 or $60 \mathrm{lb}$ per acre then the ryegrass in the sward became stunted. With up to a bushel of seed per acre. there is practically no competition between species and practically no weeds. Stock can be put on stx weeks after sowing. The bearing load of our turfs is the limiting factor as far as increased production is concerned. I think that a dense sward is essential for high density of stock per acre and a high seed rate gets a high density and high bearing load from the beginning. If we use certified seeds we should be able to reduce the amount of seed sown a little. 